\title{
Technologia HRM-PCR w diagnostyce medycznej
}

\begin{abstract}
STRESZCZENIE
Metoda wysokorozdzielczego topnienia matrycy HRM (ang. High Resolution Melting), oparta na identyfikacji różnic $w$ denaturacji produktów reakcji PCR w obecności barwników fluorescencyjnych, pozwala na identyfikację wariacji genetycznych $\mathbf{w}$ sekwencjach kwasów nukleinowych. Fakt, że analiza ta dodatkowo charakteryzuje się niskim kosztem, krótkim czasem wykonania i wysoką czułością sprawił, że znalazła ona wiele zastosowań w obszarze diagnostyki, badań laboratoryjnych oraz klinicznych. Artykuł ten stanowi przegląd literatury dotyczącej zastosowań analizy HRM w diagnostyce medycznej.
\end{abstract}

\section{WPROWADZENIE}

Reakcja łańcuchowa polimerazy - PCR (ang. Polymerase Chain Reaction) opracowana w 1993 przez Kary Mullisa cechuje się wieloma zaletami: szybkością reakcji oraz jej wydajnością, selektywnością, czułością i prostotą wykonania. Od momentu jej opracowania metoda cały czas jest modyfikowana, a jej modyfikacje znajdują coraz szersze zastosowanie. Jedną z modyfikacji jest metoda wysokorozdzielczego topnienia matrycy HRM (ang. High Resolution Melting), w której prowadzi się analizę procesu denaturacji (topnienia) zdefiniowanych fragmentów DNA (amplifikowanych w reakcji PCR). Opracowanie metody HRM-PCR było możliwe dzięki postępowi technologicznemu w zakresie aparatury i oprogramowania oraz zastosowaniu barwników fluorescencyjnych interkalujących z DNA.

Analizę HRM przeprowadza się na dwuniciowym DNA, które najpierw jest amplifikowane przy użyciu reakcji łańcuchowej polimerazy w czasie rzeczywistym RT-PCR (ang. Real Time Polymerase Chain Reaction), a następnie przechodzi do fazy topienia matrycy. Proces ten polega na powolnej denaturacji dwuniciowego DNA połączonego z interkalującym barwnikiem fluorescencyjnym, $\mathrm{w}$ temperaturze od 50 do $95^{\circ} \mathrm{C}$. Po osiągnięciu temperatury topnienia dwie nici rozdzielają się dając dwie cząsteczki jednoniciowego DNA. Punkt środkowy krzywej topnienia jest opisywany jako punkt, w którym 50\% DNA jest dwuniciowe, a 50\% jest jednoniciowe. Kształt krzywej zależy od właściwości DNA, które odnoszą się do tego, czy jest to homozygotyczny typ dziki, homozygotyczny mutant czy typ heterozygotyczny dziki i mutant. Kiedy dwie nici ulegną denaturacji, poziom fluorescencji spada. Ponieważ HRM jest monitorowane $\mathrm{w}$ czasie rzeczywistym, uzyskana krzywa topnienia daje dokładny obraz właściwości badanego DNA [1].

Zalety reakcji HRM-PCR takie jak niski koszt, krótki czas wykonania i wysoka czułość spowodowały, że metoda ta może być alternatywą dla czasochłonnych metod wykorzystujących różnice w mobilności elektroforetycznej w żelach poliakrylamidowych oraz kosztownej chromatografii dHPLC. Stale rosnąca wiedza na temat chorób genetycznych oraz pojawienie się nowych wariantów analizy HRM takich jak MS-HRM (ang. Methylation-Sensitive; HRM) sprawiły, że metoda ta stała się bardzo ważnym narzędziem w diagnostyce klinicznej.

Zrozumienie oraz identyfikacja zmienności genetycznej między poszczególnymi osobnikami i populacjami stanowi jeden z najważniejszych obszarów badań w dziedzinie genomiki. Wyjątkowy profil genetyczny warunkuje wystąpienie danej cechy lub podatność na chorobę, dlatego też poszukiwanie wiarygodnych i powtarzalnych metod wykrywania mutacji genetycznych skupia uwagę naukowców od wielu lat. Jedną z takich metod jest analiza HRM, która może być stosowana $\mathrm{z}$ wysoką wydajnością do badań pod kątem wykrywania mutacji genetycznych zarówno $w$ celach badawczych jak i klinicznych. W porównaniu do innych metod diagnostyki molekularnej pozwalających na wykrycie mutacji, mgr inż. Damian Nikodem,

\section{dr inż. Tomasz Cłapa ${ }^{\varpi}$,}

\section{dr hab. Dorota Narożna, prof. UPP}

Katedra Biochemii i Biotechnologii, Uniwersytet Przyrodniczy w Poznaniu

https://doi.org/10.18388/pb.2021_373

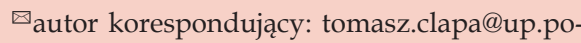
znan.pl

Słowa kluczowe: Denaturacja DNA z wysoką rozdzielczością, HRM-PCR, High Resolution Melting PCR, diagnostyka genetyczna 
wymaga mniejszego nakładu kosztów oraz czasu, zachowując wymaganą czułość oraz dokładność [2].

Do tej pory analiza HRM znalazła zastosowanie w diagnozowaniu zaburzeń genetycznych autosomalnych recesywnych, autosomalnych dominujących, sprzężonych z chromosomem $X$ oraz niedelecyjnych zaburzeń powodujących niedokrwistość tarczowatokrwinkową [3]. Potencjał tej metody jest bardzo duży co sprawia, że każdego roku spektrum jej zastosowań w celach medycznych wciąż się poszerza.

\section{ZASTOSOWANIE ANALIZY HRM W DIAGNOSTYCE AUTOSOMALNYCH RECESYWNYCH CHORÓB GENETYCZNYCH}

Rdzeniowy zanik mięśni SMA (ang. Spinal Muscular Atrophy), będący najczęstszym autosomalnym recesywnym zaburzeniem nerwowo-mięśniowym, warunkuje postępujące upośledzenie mięśni szkieletowych prowadzące w niektórych przypadkach do śmierci. Schorzenie to związane jest z mutacją genu SMN1 [4] lub polimorfizmem liczby jego kopii [5]. Wczesne wykrycie defektu w obrębie genu SMN1, a następnie terapia genowa jest najskuteczniejszą formą przeciwdziałania chorobie [6]. Chociaż dzieci z SMA często po urodzeniu nie wykazują objawów, opracowano badania przesiewowe noworodków w celu wykrycia SMA, dając możliwość rozpoczęcia leczenia bezobjawowych niemowląt [7]. Analiza HRM krwi noworodków pozwala na szybkie przesiewowe badania na dużą skalę pod kątem SMA (Ryc. 1).

Analizę HRM wykorzystuje się również w diagnostyce autosomalnej, recesywnej choroby wrodzonego przerostu nadnerczy, zaburzającej metabolizm steroidów u ludzi [8]. Ponad 90\% zachorowań spowodowanych jest mutacjami (delecje lub duplikacje) w obrębie genu kodującego 21-hydroksylazę steroidową (CYP21A2), a około 75\% wadliwych genów CYP21A2 powstaje przez rearanżacje między genem CYP21A2 a pseudogenem CYP21A1P [2]. Analiza HRM została także wykorzystana w diagnostyce choroby Wilsona - dziedziczonego, autosomalnego, recesywnego zaburzenia metabolizmu miedzi, zakłócającego funkcjonowanie wielu narządów i tkanek, wywoływanego przez mutację genu kodującego transportującą miedź adenozynotrifosfatazę (ATP7B) [9].

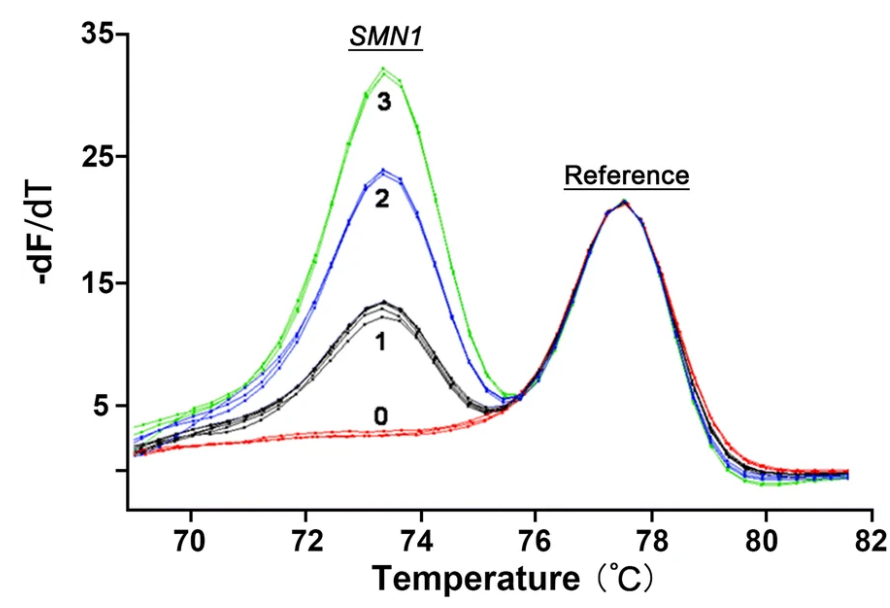

Rycina 1. Przykładowy wynik HRM-PCR dla oceny liczby kopii SMN1 w eksonie7. Zidentyfikowano próbki z 3 kopiami genu (zielone), 2 kopiami (niebieskie), 1 kopią (czarna) i 0 kopii (czerwoną). Rycina pochodzi z [5].
Innymi autosomalnymi recesywnymi chorobami, w których identyfikację chorych oraz nosicieli umożliwia analiza HRM są:

- zespół Pendreda związany z autosomalnym recesywnym wrodzonym niedosłuchem czuciowo-nerwowym, którego przyczyną są mutacje w genie SLC26A4 [10],

- hemochromatoza, która zaburza metabolizm, powodując nadmierne wchłanianie żelaza z pożywienia, wywoływana przez mutację genu HFE [11],

- zespoły Pradera-Williego - PWS (ang. Prader-Willi Syndrome) oraz Angelmana - AS (ang. Angelman Syndrome) będące rzadkimi zaburzeniami genetycznymi wywoływanymi delecjami, disomią jednorodzicielską lub defektami imprintingu na chromosomie 15. Utrata funkcji określonych genów spowodowana zmianami genetycznymi w allelu ojcowskim powoduje PWS, podczas gdy zmiany w obrębie allelu matczynego powodują AS. Ich diagnoza oraz rozróżnienie możliwe są dzięki zastosowaniu analizy MS-HRM do badania metylacji regionu promotorowego genu małego jądrowego polipeptydu rybonukleoproteiny $\mathrm{N}$, SNRPN [12].

\section{ZASTOSOWANIE ANALIZY HRM W DIAGNOSTYCE AUTOSOMALNYCH DOMINUJĄCYCH CHORÓB GENETYCZNYCH}

Zespół Marfana - MFS (ang. Marfan Syndrome), jedna z najczęściej występujących śmiertelnych wad genetycznych u dzieci, jest chorobą autosomalną dominującą, której częstość występowania szacuje się na 1 na 5000 urodzeń [13]. Występowanie MFS powiązano z około 926 mutacjami w genie fibryliny-1 (FBN1). Wykorzystanie technik sekwencjonowania w celu wykrycia mutacji genu FBN1 ze względu na jego duży rozmiar jest czasochłonne i kosztowne. Analiza HRM stanowi alternatywę dla tej techniki [14] (Ryc. 2).

Spośród zaburzeń genetycznych o charakterze autosomalnym dominującym, w których diagnostyce wykorzystywana jest analiza HRM nie można pominąć także:

- zespółu Noonana spowodowanego mutacją genu PTPN11 [15], charakteryzującego się niskorosłością, wadami rozwojowymi twarzoczaszki i serca oraz niekiedy upośledzeniem umysłowym,

- dystrofii miotonicznej, w której analizę HRM stosuje się do genotypowania polimorfizmu odcinka 1000 par zasad, obejmującego problematyczny region pięciu kolejnych elementów Alu, związanych z dystrofią miotoniczną typu 1 [16],

- autosomalnej dominującej wielotorbielowatości nerek ADPKD (ang. Autosomal Dominant Polycystic Kidney Disease) powodowanej przez mutację w obrębie genów PKD1 i PKD2. Mutacje genu PKD1 wywołują około 85\% przypadków ADPKD i są związane z cięższym przebiegiem choroby niż mutacje genu PKD2 [17]. 


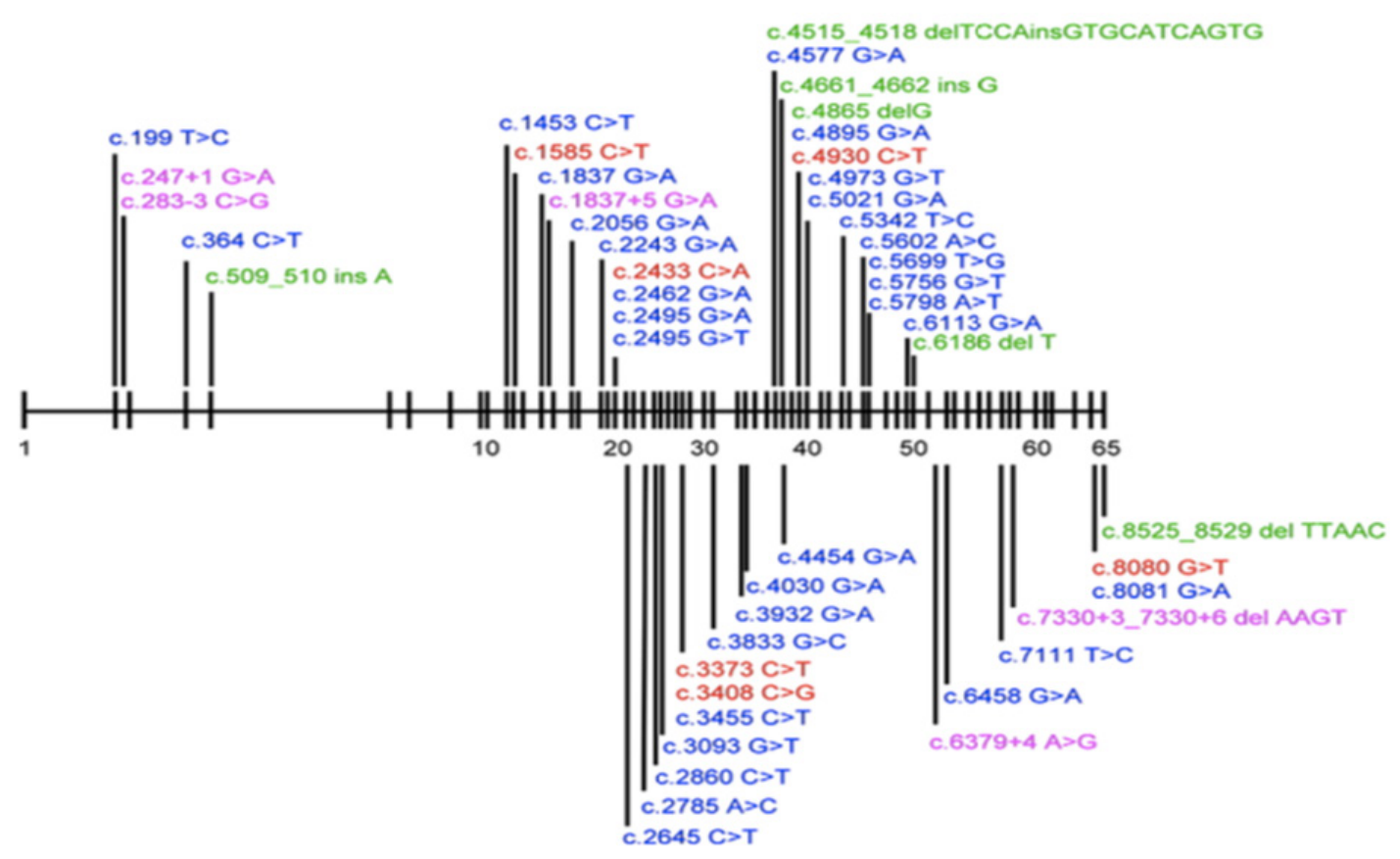

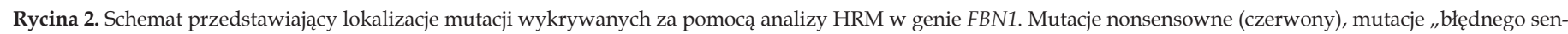
su" (niebieski), przesunięcia ramki odczytu (zielony) i mutacje miejsc wpływających na składanie RNA (fioletowy) [14].

\section{ZASTOSOWANIE ANALIZY HRM W DIAGNOSTYCE CHORÓB GENETYCZNYCH SPRZĘŻONYCH Z CHROMOSOMEM X}

Dystrofia mięśniowa Duchenne'a (DMD)/Beckera (BMD) to alleliczne choroby recesywne sprzężone $\mathrm{z}$ chromosomem $\mathrm{X}$. Ich występowanie spowodowane jest mutacjami zachodzącymi w obrębie jednego z największych, poznanych dotąd ludzkich genów - genu dystrofiny, którego rozmiar to około 2,4 miliona par zasad [18]. Spośród wszystkich mutacji wywołujących te choroby, najczęstszym defektem w genie kodującym dystrofinę jest delecja jednego lub więcej eksonów, występująca w 65\% przypadków DMD, podczas gdy duplikacja stanowi 6-10\% przypadków. Pozostałe przypadki (około 25\%) są spowodowane małymi mutacjami (mutacje „błędnego sensu”, mutacje nonsensowne oraz mutacje miejsc wpływających na składanie RNA (tzw. "splice sites”)) oraz małymi rearanżacjami (insercje, delecje czy małe inwersje). Pozostały odsetek przypadków (mniej niż 2\%) jest spowodowany złożonymi rearanżacjami i zmianami w obrębie intronów [19]. Analiza HRM, a następnie sekwencjonowanie amplikonów ze zmienionymi profilami topnienia, pozwala na wykrywanie już poznanych ale także nowych zmian u pacjentów z DMD/BMD

Tabela 1. Nieznane dotąd mutacje genu dystrofiny wykryte z pomocą analizy HRM [120].

\begin{tabular}{|c|c|c|}
\hline DMD/BMD/nosiciel & ekson & mutacja \\
\hline DMD & 7 & 597_614delinsCTAGTTTC \\
\hline DMD & 15 & $1721 G>A$ \\
\hline DMD & 22 & $2929 \mathrm{C}>\mathrm{T}$ \\
\hline DMD & 23 & 3097_3098del \\
\hline żeński nosiciel & 26 & $3516 G>A$ \\
\hline BMD & 34 & $4845+1 G>A$ \\
\hline DMD & 44 & $6291-1 G>T$ \\
\hline DMD & 45 & 6611dup \\
\hline żeński nosiciel & 51 & 7538dup \\
\hline żeński nosiciel & 58 & $8641 \mathrm{del}$ \\
\hline
\end{tabular}

Postępy Biochemii 67 (1) 2021 oraz identyfikację żeńskich nosicieli allelu warunkującego wystąpienie choroby u męskich potomków [2] (Tabela 1).

Kolejną chorobą sprzężoną z chromosomem $X$ jest Choroba Fabry'ego - FD (ang. Fabry Disease). Jej występowanie związane jest z mutacjami genu GLA kodującego białko alfa-galaktozydazę. Do tej pory z FD powiązano ponad 500 mutacji w genie GLA [21]. Analiza HRM okazała się wiarygodną i skuteczną metodą wykrywania znanych i nieznanych dotąd (-12 G>A, IVS4+68 A>G, IVS6-22 C>T) zmian w obrębie genu GLA, które następnie poddane sekwencjonowaniu pozwalają na zdiagnozowanie FD [22].

HRM jest wykorzystywany także w diagnostyce innych chorób sprzężonych z chromosomem X:

- Charcota-Marie-Tootha (CMT) typu 1, która związana jest z 296 mutacjami w obrębie genu GJB1 [2],

- przewlekłej choroby ziarniniakowej, wynikającej z mutacji w genie CYBB [23],

- rodzinnej krzywicy hipofosfatemicznej, wynikającej z mutacji w genie PHEX [24].

\section{WYKORZYSTANIE ANALIZY HRM W INNYCH OBSZARACH MEDYCYNY}

Talasemia, zwana również niedokrwistością tarczowatokrwinkową, to ilościowe zaburzenia syntezy hemoglobiny, spowodowane defektami biosyntezy łańcuchów alfa-globiny (alfa-talasemia) lub beta-globiny (beta-talasemia). Analizę HRM wykorzystuje się w celu wykrycia mutacji w obrębie genów $H B B$ [25], HBA1 i HBA2 [26], kodujących globiny. Około 7\% światowej populacji stanowią nosiciele mutacji tych genów. 
Metylacja genów w regionie promotorowym, w szczególności genów pełniących kluczowe funkcje w supresji nowotworów oraz apoptozie komórek i naprawie DNA, jest jedną z charakterystycznych cech świadczących o rozwijającym się nowotworze. Zmiany wzoru metylacji DNA, identyfikowane za pomocą analizy MS-HRM, obserwować można od wczesnych etapów rozwoju nowotworu oraz na każdym późniejszym etapie. Różne typy nowotworów często mają charakterystyczne dla siebie wzory metylacji genów i mogą służyć za markery w celu wczesnego wykrywania i/lub monitorowania progresji kancerogenezy. Ponadto metylacja niektórych genów, w szczególności tych odpowiedzialnych za naprawę DNA, może odpowiadać za wrażliwość na określoną chemioterapię [26].

Analiza HRM jest ponadto narzędziem wykorzystywanym do jednoczesnego wykrywania i genotypowania patogennych bakterii oraz wirusów [27]. Służy do wykrywania ognisk i kontroli chorób zakaźnych, monitorowania ewolucji i dynamiki populacji drobnoustrojów oraz do skutecznego nadzoru epidemiologicznego [28]. HRM, poprzedzony analizą RT-PCR może służyć jako narzędzie do jednoczesnego wykrywania i genotypowania pasożytów oraz charakterystyki genów odpowiedzialnych za ich lekooporność [30], na przykład u dzieci z niepowikłaną malarią [31].

Ostatnie badania sugerują, że depresja, która według WHO dotyka 350 milionów ludzi na całym świecie może być związana z nadprodukcją reaktywnych form tlenu i zaburzeniami biosyntezy związków katabolizujących tryptofan. Analiza MS-HRM używana jest do badań metylacji genów związanych z występowaniem objawów depresji wśród populacji szczurów narażonych na przewlekły, łagodny stres, oraz badań nad wpływem leków np. Escitalopramu [32].

Według badań z 2020 roku, HRM pozwala na wykrywanie transgenicznych świń tworzonych w celu poprawy cech ekonomicznych, poprzez zwiększenie ekspresji insulinopodobnego czynnika wzrostu typu 2.

Wariant analizy HRM z wykorzystaniem nieznakowanej sondy daje możliwość odróżnienia świń zmodyfikowanych genetycznie od świń typu dzikiego z wysoką skutecznością, szybkością i niezawodnością [33]. Jest to pierwszy przypadek, gdy analiza HRM z nieznakowaną sondą została wykorzystana do wykrywania świń z edytowanym genomem za pomocą technologii CRISPR/Cas9. Możliwość zastosowania tej metody do szybkiego wykrywania materiału genetycznego edytowanego z użyciem technologii CRISPR/ Cas9, sugeruje możliwość wykorzystania jej w celu monitorowania przebiegu terapii genowych.

\section{PODSUMOWANIE}

Streszczenie graficzne omawianego materiału przedstawia rycina 3. Ogromny potencjał, prostota oraz szybkość analizy HRM, sprawiają że ciągle pojawiają się doniesienia o nowych zastosowaniach tej technologii w medycynie, jak również innych obszarach codziennego życia. Obok wielu zalet, metoda ta posiada jednak kilka ograniczeń: podczas analizy, stężenie matrycy DNA musi być równe dla prób badanych i kontroli; w celu wykonania analizy mutacji na poziomie RNA, niezbędna jest wcześniejsza ilościowa ocena badanego transkryptu; w przypadku mutacji somatycznych czułość HRM jest wyższa niż sekwencjonowania, co skutkuje trudnością w ocenie obecności mutacji o niskim mianie; metoda generuje pewne ilości odczytów fałszywie pozytywnych.

Zalety metody HRM dominują nad jej ograniczeniami co sprawia, że metoda jest preferowanym narzędziem do badań przesiewowych pacjentów pod kątem wielu zaburzeń genetycznych.

\section{PIŚMIENNICTWO}

1. Foroni L, Reid AG, Gerrard G, Toma S, Hing S (2017) Molecular and Cytogenetic Analysis. Dacie and Lewis Practical Haematology, Elsevier: $126-64$

2. Er TK, Chang JG (2012) High-resolution melting: Applications in genetic disorders. Clin Chim Acta 414: 197-201

3. Liu YN, Li R, Li J, Li DZ (2011) Rapid identification of hemoglobin Quong Sze mutation using high-resolution melting analysis: LETTER TO THE EDITOR. Int J Lab Hematol 33: e5-e6

4. Dobrowolski SF, Pham HT, Pouch Downes F, Prior TW, Naylor EW, Swoboda KJ (2012) Newborn screening for spinal muscular atrophy by calibrated short-amplicon melt profiling. Clin Chem 58: 1033-1039

5. Zhang X, Wang B, Zhang L, You G, Palais RA, Zhou L, Fu Q (2018) Accurate diagnosis of spinal muscular atrophy and 22q11.2 deletion
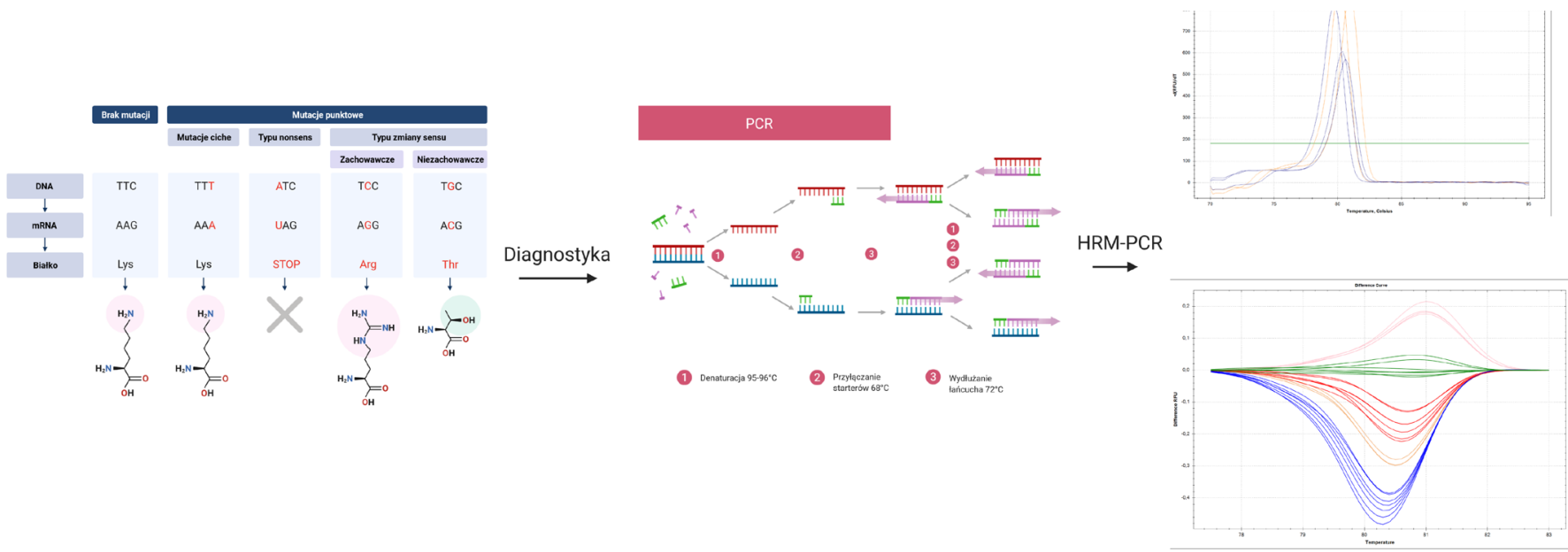

Rycina 3. Streszczenie graficzne. 
syndrome using limited deoxynucleotide triphosphates and high-resolution melting. BMC Genomics 19(1): 485

6. Foust KD, Wang X, McGovern VL, Braun L, Bevan AK, Haidet AM, et al. (2010) Rescue of the spinal muscular atrophy phenotype in a mouse model by early postnatal delivery of SMN. Nat Biotechnol 28: 271-274

7. Prior TW, Snyder PJ, Rink BD, Pearl DK, Pyatt RE, Mihal DC, et al. (2010) Newborn and carrier screening for spinal muscular atrophy. Am J Med Genet 152A: 1608-1166

8. Balsamo A, Baronio F, Ortolano R, Menabo S, Baldazzi L, Di Natale V, et al. (2020) Congenital Adrenal Hyperplasias Presenting in the Newborn and Young Infant. Front Pediatr 8: 593315

9. Lin C-W (2010) Development of a high-resolution melting method for the screening of Wilson disease-related ATP7B gene mutations. Clin Chim Acta 411(17-18): 1223-1231

10. Chen N, Tranebj L, Rendtorff ND, Schrijver I (2011) Mutation Analysis of SLC26A4 for Pendred Syndrome and Nonsyndromic Hearing Loss by High-Resolution Melting 13: 11

11. Santos PCJL, Soares RAG, Krieger JE, Guerra-Shinohara EM, Pereira AC (2011) Genotyping of the hemochromatosis HFE p.H63D and p.C282Y mutations by high-resolution melting with the Rotor-Gene $6000 \circledast$ instrument. Clin Chem Lab Med 49(10): 1633-1636

12. Ribeiro Ferreira I, Darleans dos Santos Cunha W, Henrique Ferreira Gomes L, Azevedo Cintra H, Lopes Cabral Guimarães Fonseca L, Ferreira Bastos E, et al. (2019) A rapid and accurate methylation-sensitive high-resolution melting analysis assay for the diagnosis of Prader Willi and Angelman patients. Mol Genet Genomic Med: e637

13. Paepe AD, Devereux RB, Dietz HC, Hennekam RCM, Pyeritz RE (1996) Revised diagnostic criteria for the Marfan syndrome. Am J Med Genet 62(4): 417-426

14. Hung CC, Lin SY, Lee CN, Cheng HY, Lin CY, Chang CH, et al. (2009) Identification of fibrillin- 1 gene mutations in Marfan syndrome by high-resolution melting analysis. Anal Biochem 389: 102-106

15. Lo FS, Luo JD, Lee YJ, Shu SG, Kuo MT, Chiou CC (2009) High resolution melting analysis for mutation detection for PTPN11 gene: Applications of this method for diagnosis of Noonan syndrome. Clin Chim Acta 409: 75-77

16. Radvansky J, Resko P, Surovy M, Minarik G, Ficek A, Kadasi L (2009) High-resolution melting analysis for genotyping of the myotonic dystrophy type 1 associated Alu insertion/deletion polymorphism. Anal Biochem 398: 126-128

17. Bataille S, Berland Y, Fontes M, Burtey S (2011) High Resolution Melt analysis for mutation screening in PKD1 and PKD2. BMC Nefrol 12: 57

18. Den Dunnen JT, Grootscholten PM, Bakker E, Blonden LAJ, Ginjaar HB, Wapenaar MC, vanPaassen HMB, vanBroeckhoven C, Pearson tR L, van Ommen GJB (1989) Topography of the Duchenne Muscular Dystrophy (DMD) Gene: FIGE and cDNA Analysis of 194 Cases Reveals 115 Deletions and 13 Duplications. Am J Hum Genet 45(6): 835-847

19. Falzarano M, Scotton C, Passarelli C, Ferlini A. Duchenne (2015) Duchenne Muscular Dystrophy: From Diagnosis to Therapy. Molecules 20: 18168-18684
20. Almomani R, van der Stoep N, Bakker E, den Dunnen JT, Breuning MH, Ginjaar IB (2009) Rapid and cost effective detection of small mutations in the DMD gene by high resolution melting curve analysis. Neuromuscular Dis 19: 383-390

21. Hwu WL, Chien YH, Lee NC, Chiang SC, Dobrovolny R, Huang AC, et al. (2009) Newborn screening for Fabry disease in Taiwan reveals a high incidence of the later-onset GLA mutation c.936+919G>A (IVS4+919G>A). Hum Mutat 30: 1397-1405

22. Bono C, Nuzzo D, Albeggiani G, Zizzo C, Francofonte D, Iemolo F, et al. (2011) Genetic screening of Fabry patients with EcoTILLING and HRM technology. BMC Res Notes 4: 323

23. Hill HR, Augustine NH, Pryor RJ, Reed GH, Bagnato JD, Tebo AE, et al. (2010) Rapid Genetic Analysis of X-Linked Chronic Granulomatous Disease by High-Resolution Melting. J Mol Diagn 12: 368-376

24. Gaucher C, Walrant-Debray O, Nguyen T-M, Esterle L, Garabédian M, Jehan F. (2009) PHEX analysis in 118 pedigrees reveals new genetic clues in hypophosphatemic rickets. Hum Genet 125(4): 401-411

25. Shih HC, Er TK, Chang TJ, Chang YS, Liu TC, Chang JG (2009) Rapid identification of HBB gene mutations by high-resolution melting analysis. Clin Biochem 42(16-17): 1667-1676

26. Shih HC, Er TK, Chang TJ, Chang YS, Liu TC, Chang JG (2010) Development of a high-resolution melting method for the detection of hemoglobin alpha variants. Clin Biochem 43(7-8): 671-676

27. Wojdacz TK, Dobrovic A (2007) Methylation-sensitive high resolution melting (MS-HRM): a new approach for sensitive and high-throughput assessment of methylation. Nucleic Acids Res 35: e41-e41

28. Tong SYC, Giffard PM (2012) Microbiological Applications of High-Resolution Melting Analysis. J Clin Microbiol 50: 3418-3421

29. Tamburro M, Ripabelli G (2017) High Resolution Melting as a rapid, reliable, accurate and cost-effective emerging tool for genotyping pathogenic bacteria and enhancing molecular epidemiological surveillance: a comprehensive review of the literature. Ann Ig 29(4): 293-316

30. Mohammad Rahimi H, Pourhosseingholi MA, Yadegar A, Mirjalali H, Zali MR (2019) High-resolution melt curve analysis: A real-time based multipurpose approach for diagnosis and epidemiological investigations of parasitic infections. Comp Immunol Microbiol Infect Dis 67: 101364

31. Kayode AT, Ajogbasile FV, Akano K, Uwanibe JN, Oluniyi PE, Eromon PJ, et al. (2021) Polymorphisms in Plasmodium falciparum dihydropteroate synthetase and dihydrofolate reductase genes in Nigerian children with uncomplicated malaria using high-resolution melting technique. Sci Rep 11: 471

32. Wigner P, Synowiec E, Jóźwiak P, Czarny P, Bijak M, Białek K, et al. (2020) The effect of chronic mild stress and escitalopram on the expression and methylation levels of genes involved in the oxidative and nitrosative stresses as well as tryptophan catabolites pathway in the blood and brain structures. Int J Mol Sci 22(1): 10

33. Liu X, Qiu S, Mei L, Jing H, Lin X, Wang Q (2020) A High-Resolution Melting Analysis with an Unlabeled Probe for CRISPR/Cas9-Induced ZBED6 Knockout Pigs Detection. J AOAC Int. doi: 10.1093/jaoacint/ qsaa161

\section{HRM-PCR in medical diagnostic}

\section{Damian Nikodem ${ }^{1}$, Tomasz Cłapa ${ }^{1}$, Dorota Narożna ${ }^{1}$}

${ }^{1}$ Department of Biochemistry and Biotechnology, Poznan University of Life Sciences, Dojazd 11, 60-632 Poznań, Poland

Keywords: HRM-PCR, High Resolution Melting PCR, genetic diagnostics, sequence identification

\section{ABSTRACT}

High resolution melting (HRM) is a method based on the identification of differences in the denaturation of PCR reaction products in the presence of fluorescent dyes. It allows for a detailed analysis of the genetic profiles. In addition this analysis is low-cost, single-step, closed-tube and has high sensitivity. HRM found applications in diagnostics, laboratory and clinical researches. This article is a literature review of the applications of HRM analysis in medicine.

Acknowledgement: The graphical abstract was create by using: BioRender.com 